九州大学学術情報リポジトリ

Kyushu University Institutional Repository

\title{
Structures of Felling and Reforestation of Private Forests in Korea
}

\section{Kang, Hag Mo}

Department of Forest Resoruces, College of Agriculture, Sunchon National University

Okamori, Akinori

Laboratoy of Forest Policy, Division of Forest Environment and Management Sciences, Department of Forest and Forest Prodcuts Sciences, Faculty of Agriculture, Kyushu University

Lee, Chang Heon

Faculty of Forest Science, College of Agriculture, (the Institute Agricultural Science and Technology) Chonbuk National University

Park, Chong Min

Faculty of Forest Science, College of Agriculture, (the Institute Agricultural Science and Technology) Chonbuk National University

他

https://doi.org/10.5109/24413

出版情報: 九州大学大学院農学研究院紀要. 45 (2)，pp.631-642，2001-02-28. Kyushu University バージョン：

権利関係 : 


\title{
Structures of Felling and Reforestation of Private Forests in Korea
}

\author{
Hag Mo Kang', Akinori Okamori², Chang Heon Lee ${ }^{3}$, Chong Min Park ${ }^{3}$, \\ Sang Hyun Lee ${ }^{3}$, Seung Won $\mathrm{Oh}^{3}$, and Ki Wan $\mathrm{An}^{4}$
}

\author{
${ }^{2}$ Laboratory of Forest Policy, Division of Forest Environment and Management Sciences, \\ Department of Forest and Forest Products Sciences, Faculty of Agriculture, \\ Kyushu University, Fukuoka 812-8581, Japan \\ (Received October 13, 2000 and accepted November 10, 2000)
}

\begin{abstract}
Korea is now promoting the 4 th basic forestry plan for continuous forest management based on the success of the $1 \mathrm{st} \cdot 2$ nd erosion controls and greening projects, and the forest materialization project started in 1973. However, the management conditions of private forests, which occupy $71 \%$ of all forest land, are gradually getting worse due to small-scale possession, the uprising of pay, the deficiency of labor and the increase of non-resident forest owners. Hence, forest owners are avoiding the investment of labor forces and funds, and most of plantation forests, which occupy over $30 \%$ of Korea forest land, is not conserved. Thus, this study was carried out to find a way which forest owners can participate in forest management more actively than ever through the comprehension of the structure of felling and reforestation. As a result, the felling and reforestation structure of the private forests of Sunchon city of Chonnam province and Changsu county of Chonbuk province feature a different use of form. And we also have come to the conclusion that the felled trees distribution structure and the tree market development figures throughout Chonnam and Chonbuk provinces require broader study, as well as the object area of this investigation, to clarify the use of felled trees and sale structures.
\end{abstract}

\section{INTRODUCTION}

Korea relied on the $3 \mathrm{rd}$ basic forestry plan (1988 1997) for the purpose of maximization of forest efficiency through at the 1st erosion control and greening project, which focused on using fast-growing trees for fuel; and the 2 nd erosion control and greening project placed great importance on the establishment of economical trees. And now in 2000 , the 4 th basic forestry plan (1998 2007) being promoted aims at the construction of a management base as well as an administration system and the realization of the need for continuous forest management.

However, looking at the government's estimation of toward the 3rd basic forestry plan, completed in 1997, one sees that they indicated that forest owners had a tendency to avoid investment in reforestation, owing to the price tie-up of indigenous timber and the deficiency of labor force in rural mountain villages. The 'silviculture and thinning

\footnotetext{
' Department of Forest Resources, College of Agriculture, Sunchon National University, Sunchon 540-742, Korea

${ }^{3}$ Faculty of Forest Science, College of Agriculture, (The Institute Agricultural Science and Technology), Chonbuk National University, Chonju 561-756, Korea

${ }^{4}$ Department of Forestry, College of Agriculture, Chonnam National University, Kwangju 500-757, Korea
} 
project' bore no fruit from the failure of reforestation land because of the indifference of forest owners and low rates of assistance (Forestry Administration, 1997b).

The government has a plan to secure sufficient forestry labor through the cultivation of forest craft workers and reduction of burden on forest owners by magnifying assistance funds. The negligence towards plantation forests, however, is on the increase because of no earnings from thinning (Kang, 1994).

However, in this situation the number of possible pulpwood and general timber supplies is increase, but the rate of self-sufficiency is still decreasing every year. It especially seems difficult to achieve a timber self-sufficiency rate of $60 \%$ by 2040 , to which government plan aims based on factors, such as the demand decrease of mine-props trees of indigenous timber, the structure of wood consumption dependent on foreign one, and the uprising expenses of indigenous timber production (Chang and Seok, 1992).

Therefore, reforestation and the magnification of economical wood species of inferior forest areas are strongly recommended, but an active participation of forest owners is the most important ingredient required to realize this goal.

Therefore, the objective of this study is to find a way forest owners can actively participate in forest management through understanding the structure of felling and reforestations which applies to private forests of two areas: Sunchon city in Chonnam and Changsu county in Chonbuk province.

\section{MATERIALS AND METHODS}

\section{Investigation Areas}

Two investigation areas were selected: Sunchon city in Chonnam province mixed district with urban and rural features which magnify the planting of trees for nuts and fruits, and Changsu county in Chonbuk province, which is a rural mountain district where trees for timber production are being planted continuously.

First, Sunchon city in Chonnam province is situated in the southwestern part of Korea. It has a mild climate and also has many kinds of fruit trees, such as persimmons, chestnuts, strawberries, peaches, flowering plants, and decorative plants which are widely cultivated. Since 1995, due to an integration with Sungju county, we have called Sunchon city an urban rural mixed region, one with a population of 270,000 . The forest size is $64,000 \mathrm{ha}$, which occupies $9 \%$ of all Chonnam province forest lands, and $711,000 \mathrm{ha}$, which both make up the and broadest region among 22 other cities and counties in Chonnam province.

Changsu county in Chonbuk province is situated about 100 kilometers away from Sunchon city toward the north. It is 430 meters above sea level, so high-cold land vegetables, such as Chinese cabbages, radishes, tobaccos, ginseng, and apples are widely cultivated in that region. It is a rural mountain area that has a population of 30,000 under the state of depopulation. The forest size is 41,000 ha, which occupies $9 \%$ of Chonbuk province forest lands of $456,000 \mathrm{ha}$, and is a little broader than the average size of 14 other cities and counties of 33,000 ha. Major species reforested artificially are larches, pitch pines, Korean nut pines, and the growing stock account for $13 \%, 15 \%$ and $20 \%$ of the total stock, respectively. 


\section{Investigation methods}

The investigation was performed for three months from January to March in 1999. Forty people at Sunchon city in Chonnam and 32 people at Changsu county in Chonbuk provinces were investigated via an interview among resident forest owners, who obtained permission for clear cutting for 4 years from 1995 to 1998.

Investigation substance contains labor force constituent, forest possession structure, felling labor force, the uses of funds and felled trees, reforestation labor force and funds, species of reforestation, and forestry incomes as well as forest management plan.

\section{RESULTS AND DISCUSSION}

1. General Situation of Forest Growing Stock and Supply \& Demand in Korea

National forests and public forests each takes $22 \%$ and $8 \%$ of all Korean total forest

Table 1. Status of national forest land area and growing stock

\begin{tabular}{|c|c|c|c|c|c|c|c|}
\hline \multicolumn{4}{|c|}{ Area $(1,000 \mathrm{ha})$} & \multicolumn{4}{|c|}{ Growing stock $\left(1,000 \mathrm{~m}^{3}\right)$} \\
\hline Total & $\begin{array}{c}\text { National } \\
\text { foreat }\end{array}$ & $\begin{array}{l}\text { Public } \\
\text { forest, }\end{array}$ & $\begin{array}{c}\text { Private } \\
\text { foreat }\end{array}$ & Total & $\begin{array}{c}\text { National } \\
\text { foreat }\end{array}$ & $\begin{array}{l}\text { Public } \\
\text { forest }\end{array}$ & $\begin{array}{c}\text { Private } \\
\text { foreat }\end{array}$ \\
\hline $\begin{array}{r}6,451 \\
(100.0)\end{array}$ & $\begin{array}{r}1,419 \\
(22.0)\end{array}$ & $\begin{array}{r}487 \\
(7.5)\end{array}$ & $\begin{array}{r}4,545 \\
(70.5)\end{array}$ & $\begin{array}{r}363,561 \\
(100.0)\end{array}$ & $\begin{array}{r}115,878 \\
(31.9)\end{array}$ & $\begin{array}{r}27,321 \\
(7.5)\end{array}$ & $\begin{array}{r}220,362 \\
(60.6)\end{array}$ \\
\hline
\end{tabular}

Sources: Forestry Administration. 1999. Statistical yearbook of forestry. 26-27 pp.

Note: Numerical Values of inside in the parentheses are percent of composition.

Table 2. Accomplishment of reforestation

\begin{tabular}{|c|c|c|c|c|c|c|}
\hline & Total $(1,000$ ha $)$ & $\begin{array}{l}\text { Long rotation } \\
\text { species }\end{array}$ & $\begin{array}{l}\text { Fast rotation } \\
\text { species }\end{array}$ & $\begin{array}{l}\text { Fruit nut } \\
\text { species }\end{array}$ & Fuel species & others \\
\hline Total & $\begin{array}{r}2,398 \\
(100.0)\end{array}$ & $\begin{array}{r}1,133 \\
(47.2)\end{array}$ & $\begin{array}{r}830 \\
(34.6)\end{array}$ & $\begin{array}{r}199 \\
(8.3)\end{array}$ & $\begin{array}{r}208 \\
(8.7)\end{array}$ & $\begin{array}{r}28 \\
(1.2)\end{array}$ \\
\hline $\begin{array}{l}\text { 1st periods of erosion } \\
\text { control and greening } \\
\text { project }(1973-1978)\end{array}$ & $\begin{array}{r}1,080 \\
(100.0)\end{array}$ & $\begin{array}{r}358 \\
(33.1)\end{array}$ & $\begin{array}{r}360 \\
(33.3)\end{array}$ & $\begin{array}{r}154 \\
(14.3)\end{array}$ & $\begin{array}{r}208 \\
(19.3)\end{array}$ & \\
\hline $\begin{array}{l}\text { 2ed periods of erosion } \\
\text { control and greening } \\
\text { project }(1979 \sim 1988)\end{array}$ & $\begin{array}{r}997 \\
(100.0)\end{array}$ & $\begin{array}{r}531 \\
(53.3)\end{array}$ & $\begin{array}{r}437 \\
(43.8)\end{array}$ & $\begin{array}{r}29 \\
(2.9)\end{array}$ & & \\
\hline $\begin{array}{l}\text { 3rd basic forestry plan } \\
(1988 \sim 1997)\end{array}$ & $\begin{array}{r}321 \\
(100.0)\end{array}$ & $\begin{array}{r}244 \\
(76.0)\end{array}$ & $\begin{array}{r}33 \\
(10.3)\end{array}$ & $\begin{array}{r}16 \\
(5.0)\end{array}$ & & $\begin{array}{r}28 \\
(8.7)\end{array}$ \\
\hline
\end{tabular}

Sources: 1) Forestry Administration. 1996. A propulsion plan of priciple forest policy.

2) Forestry Administration. 1997. History of 50 years of forest policy in Korea.

3) Forestry Administration. 1999. Statistical yearbook of forestry.

Note: 1) Fruit nut species: chestnut, persimmon trees etc.

Fast growing species: Italian poplar, paulownia etc.

Long rotation species: Korean wihite pine, larch etc.

Fuel species: False acacia, alder etc.

Others: Lacquer tree etc.

2) Numerical Values of inside in the parentheses are percent of composition. 
land, but private forests account for $71 \%$. The growing stock per hectare of national forests are $82 \mathrm{~m}^{3}$, public forests $56 \mathrm{~m}^{3}$ and private forest $48 \mathrm{~m}^{3}$, respectively, private forest are the lowest (Table1).

The forest growing stock has increased from a total of $72,696,000 \mathrm{~m}^{3}\left(11 \mathrm{~m}^{3} / \mathrm{ha}\right)$ in 1972 to $363,561,000 \mathrm{~m}^{3}\left(56 \mathrm{~m}^{3} / \mathrm{ha}\right)$ in 1999 . The government has set a goal for long term reforestation to increase plantation forests and timber self-supply rates which stood at $32 \%$ and $13 \%$, respectively, in 1996 and should increase to $50 \%$ and $60 \%$ by 2040 (Table 2) (Forestry Administration, 1996; 1997a; 1997b; 1998).

However, forestry production which occupied $1.8 \%$ ( $\$ 851,300,000$ ) of the GNP decreased to $0.2 \%$ ( $\$ 752,600,000)$ in 1998 . Also, in spite of timber demand continuously on the increase, the self-supply rate of indigenous timber has been no more than $13 \%$ for the past 9 years from 1990 to 1998 (Forestry Administration, 1999). More than half the number of indigenous timber is used as low vàlue usage, such as mine-props trees or pulpwood, and in the case of general wood, they are mostly used as packing wood rather than interior wood for construction.

Table 3. Forest products and timber demand and supply by year

\begin{tabular}{|c|c|c|c|c|c|c|c|c|c|}
\hline & \multicolumn{3}{|c|}{$\begin{array}{l}\text { Forest products } \\
\text { (Billion won) }\end{array}$} & \multicolumn{6}{|c|}{ Timber demand and supply $\left(1,000 \mathrm{~m}^{3}\right)$} \\
\hline & \multirow[b]{2}{*}{ GNP } & \multirow[b]{2}{*}{ Forestry } & \multicolumn{3}{|c|}{ Origin } & \multicolumn{4}{|c|}{ Domestic } \\
\hline & & & Total & Domestic & Import & Total & $\begin{array}{c}\text { Pit } \\
\text { prop }\end{array}$ & $\begin{array}{l}\text { Pulp } \\
\text { wood }\end{array}$ & $\begin{array}{c}\text { General } \\
\text { wood }\end{array}$ \\
\hline 1990 & $3,070,038$ & 8,330 & 80,102 & 10,644 & 69,458 & 10,644 & 2,185 & 3,552 & 4,907 \\
\hline$\sim 1998$ & & & $(100.0)$ & $(13.3)$ & $(86.7)$ & $(100.0)$ & $(20.5)$ & $(33.4)$ & $(46.1)$ \\
\hline 1990 & 263,952 & 1,165 & 9,423 & 1,138 & 8,285 & 1,138 & 512 & 410 & 216 \\
\hline 1993 & 321,267 & 874 & 8,832 & 1,184 & 7,648 & 1,184 & 227 & 346 & 611 \\
\hline 1995 & 376,316 & 853 & 9,284 & 1,055 & 8,229 & 1,055 & 139 & 405 & 511 \\
\hline 1998 & 370,862 & 824 & 5,798 & 1,428 & 4,370 & 1,428 & 110 & 406 & 912 \\
\hline
\end{tabular}

Sources: Forestry Administration. 1999. Statistical yearbook of forestry. 246-337 pp.

Note: Numerical Values of inside in the parentheses are percent of composition.

\section{Felling and Reforestation Structure of Investigation Areas}

1) The General Situation

The forest size of Sunchon city of Chonnam province is 64,000 ha and private forests account for $88 \%$. Forest growing stock is $44 \mathrm{~m}^{3} / \mathrm{ha}$, which is almost the same level as Chonnam province $\left(41 \mathrm{~m}^{3} / \mathrm{ha}\right)$. In private forests, residents and non-residents each owned $48 \%$ and $52 \%$, and the number of forest owners account for $56 \%$ and $44 \%$, respectively. Forest possession scales per one owner are 1.9 ha and 2.6 ha to residents and non-residents, respectively. Clear cutting size per one forest owner is 2.2 ha to residents, 4.3 ha to non-residents in their areas.

The forest size of Changsoo county of Chonbuk province is 41,000 ha, and private forests are $77 \%$ of that figure. The forest growing stocks are $57 \mathrm{~m}^{3} /$ ha which is almost the same level as Chonbuk province, which amounts to $53 \mathrm{~m}^{3} / \mathrm{ha}$. In private forests, residents and non-residents each possessed $48 \%$ and $52 \%$, and the number of forest owners 
account for $43 \%$ and $57 \%$, respectively. The forest possession scales per one owner are $6.8 \mathrm{ha}$ and $6.3 \mathrm{ha}$ for residents and non-residents, respectively. The clear cutting areas for the 4 years from 1995 to 1998 are 976 ha, which account for $3.1 \%$ of the total private

Table 4. Status of private forest ownership in investigation areas

\begin{tabular}{lrrrrrrr}
\hline & \multicolumn{3}{c}{ Forest areas (1,000 ha) } & & \multicolumn{2}{c}{ Forest owners (1,000 people) } \\
\cline { 2 - 4 } \cline { 6 - 7 } Sunchon & \multicolumn{1}{c}{ Total } & Resident & Absentee & & Total & Resident & Absentee \\
\hline \multirow{3}{*}{ Changsu } & 56.3 & 26.9 & 29.4 & & 25.7 & 14.5 & 11.2 \\
& $(100.0)$ & $(47.8)$ & $(52.2)$ & & $(100.0)$ & $(56.4)$ & $(43.6)$ \\
& 31.9 & 14.3 & 17.6 & & 4.9 & 2.1 & 2.8 \\
& $(100.0)$ & $(44.8)$ & $(55.2)$ & & $(100.0)$ & $(42.9)$ & $(57.1)$ \\
\hline
\end{tabular}

Sources: Forestry Administration. 1999. Statistical yearbook of forestry. 148-149 pp. Note: Numerical Values of inside in the parentheses are per-cent of composition.

Table 5. Status of tree cutting in investigation areas (1995 - 1998)

\begin{tabular}{|c|c|c|c|c|c|c|c|}
\hline & \multicolumn{4}{|c|}{ Cutting areas (ha) } & \multicolumn{3}{|c|}{ Forest owners (people) } \\
\hline & Forest/owner & Total & Resident & Absentee & Total & Resident & Absentee \\
\hline \multirow{2}{*}{ Sunchon } & 2.5 & 1,003 & 730 & 273 & 399 & 336 & 63 \\
\hline & & $(100.0)$ & $(72.8)$ & $(27.2)$ & $(100.0)$ & $(84.2)$ & $(15.8)$ \\
\hline \multirow[t]{2}{*}{ Changsu } & 2.9 & 976 & 757 & 219 & 337 & 252 & 85 \\
\hline & & $(100.0)$ & $(77.6)$ & $(22.4)$ & $(100.0)$ & $(74.8)$ & $(25.2)$ \\
\hline
\end{tabular}

Note: Numerical Values of inside in the parentheses are percent of composition.

forest areas. The clear cutting size per one forest owner is 3.0 ha for residents, 2.6 ha for non-residents in their areas (Tables 4 and 5) (Forestry Administration, 1999).

2) General Conditions of Interviewee

(1) Components of Labor Force

In the case of Sunchon city, investigation subject, 40 people inhabits 109 households in all, 2.7 persons per house on average. Classified by age, people over fifty and sixty account for $30 \%$ and $41 \%$, respectively, therefore, old age groups take the leading role, and the average age of 40 forest owners is 59 years of age.

Below are employment details of the young classes, 31 persons in their twenties thirties: students 11, household workers (agriculture) 11, agriculture workers 4, independent business owners 3 and company employees 2 . So the members of households engaging in agriculture is few.

In case of Changsu county, investigation subject, there are 76 people inhabiting 32 households in all, 2.4 person per house on average. These people over fifty or sixty account for $20 \%$ and $58 \%$, most of them in the oldest age group and the average age of 32 forest owners is 63 years. And looking at employment details of 17 persons between ages 20 and 40: agriculture workers 4, students 2 , forest laborers 1, unknown 2.

(2) Forest Possession Structures

In Sunchon city, the entire forest possession sizes of 40 investigation subjects are $197 \mathrm{ha}$, and the average possession scale per one forest owner is 4.9 ha. Fifty-four per- 
cent and $46 \%$ of possession forests are composed of plantation forests and natural forests in sequence, but comparatively small scales of under 3 ha have high rates of plantation forests.

In Changsu county, the entire forest possession sizes of 32 investigation subjects are $183 \mathrm{ha}$, and the average possession scale per one forest owner is 5.7 ha. Eighty percent

Table 6. Status of forest ownership of investigation objects (forest owners)

\begin{tabular}{|c|c|c|c|c|c|c|c|c|}
\hline & \multirow{2}{*}{$\begin{array}{l}\text { Owners } \\
\text { (people) }\end{array}$} & \multirow{2}{*}{$\begin{array}{c}\text { Total/ } \\
\text { owner(ha) }\end{array}$} & \multirow{2}{*}{$\begin{array}{l}\text { Total } \\
\text { (ha) }\end{array}$} & \multicolumn{3}{|c|}{ Plantation forests } & \multirow{2}{*}{$\begin{array}{c}\text { Natural } \\
\text { forest }\end{array}$} & \multirow{2}{*}{$\begin{array}{c}\text { Non-stoc } \\
\text { ked }\end{array}$} \\
\hline & & & & Sub-total & Existing forest & New forest & & \\
\hline \multirow[t]{2}{*}{ Sunchon } & 40 & 4.9 & 196.5 & 105.2 & 48.4 & 56.8 & 91.1 & 0.2 \\
\hline & & & $(100.0)$ & $(53.5)$ & $(46.0)^{*}$ & $(54.0)^{*}$ & $(46.4)$ & $(0.1)$ \\
\hline \multirow[t]{2}{*}{ Changsu } & 32 & 5.7 & 182.6 & 145.6 & 71.1 & 74.5 & 32.0 & 5.0 \\
\hline & & & $(100.0)$ & $(79.7)$ & $(38.9)$ & $(40.8)$ & $(17.5)$ & $(2.7)$ \\
\hline
\end{tabular}

Note: 1) New plantation forests mean that forests were established in bet-ween 1995 and 1998 .

2) Numerical Values of inside in the parentheses with star simbol are percent of composition about sub-total of plantation.

3) Numerical Values of inside in the parentheses are percent of com-position.

and $18 \%$ of possession forests are composed of plantation forests and natural ones in sequence, but each class has a high rate of plantation forests (Table 6).

(3) Forest Constituent of Plantation Forest

In Sunchon city, chestnut trees and pitch pines account for $71 \%$ of its forests and $9 \%$, respectively in 48 ha among whole plantation forests of 105 ha. In newly established plantation forests of 57 ha from 1995 to 1998, chestnut trees and Gorosoi trees (Acer mono) account for $41 \%$ and $23 \%$, respectively, but there are almost no trees for timber production. And among existed plantation forests, pitch pines for timber production are hardly taken care of. Naturals forests with inferior conditions, such as steep slopes, mostly highland, and do not seem to be used actively because of the deficiency of laborers and low profitability.

In Changsu county, among plantation forest of 146 ha there are $48 \%$ larches, $24 \%$ pitch pines and $23 \%$ Korean nut pines in 71 ha. In newly established plantation forests from 1995 to 1998 , chestnut trees and larches accounted for $45 \%$ and $33 \%$. Meanwhile,

Table 7. Composition of species in plantation

\begin{tabular}{|c|c|c|c|c|c|c|c|c|c|c|}
\hline & \multirow{2}{*}{$\begin{array}{l}\text { Total } \\
\text { (ha) }\end{array}$} & \multicolumn{5}{|c|}{ Existing plantation(ha) } & \multicolumn{4}{|c|}{ New plantation(ha) } \\
\hline & & $\begin{array}{l}\text { Sub- Chest- } \\
\text { total nut }\end{array}$ & Larch & $\begin{array}{l}\text { Pitch } \\
\text { pine }\end{array}$ & $\begin{array}{c}\text { Korean } \\
\text { white } \\
\text { pine }\end{array}$ & Others & $\begin{array}{l}\text { Sub- Chest- } \\
\text { total nut }\end{array}$ & Gorosoi Larch & $\begin{array}{c}\text { Korean } \\
\text { white } \\
\text { pine }\end{array}$ & Others \\
\hline Sunchon & 105.2 & $\begin{array}{rr}48.4 & 34.4 \\
(100.0) & (71.1)\end{array}$ & & $\begin{array}{r}9.8 \\
(20.2)\end{array}$ & & $\begin{array}{r}4.2 \\
(8.7)\end{array}$ & $\begin{array}{r}56.8 \quad 23.4 \\
(100.0)(41.2)\end{array}$ & $\begin{array}{r}12.8 \\
(22.5)\end{array}$ & & $\begin{array}{r}20.6 \\
(36.2)\end{array}$ \\
\hline Changsu & 145.6 & $\begin{array}{r}71.1 \\
(100.0)\end{array}$ & $\begin{array}{r}33.9 \\
(47.7)\end{array}$ & $\begin{array}{r}17.2 \\
(24.2)\end{array}$ & $\begin{array}{r}16.0 \\
(22.5)\end{array}$ & $\begin{array}{r}4.0 \\
(5.6)\end{array}$ & $\begin{array}{r}74.5 \\
(100.0)\end{array}$ & $\begin{array}{r}24.7 \\
(33.2)\end{array}$ & $\begin{array}{r}33.2 \\
(44.6)\end{array}$ & $\begin{array}{r}16.6 \\
(22.3)\end{array}$ \\
\hline
\end{tabular}

Note: Numerical Values of inside in the parentheses are percent of composition. 
the reforestation of pitch pines reduced suddenly and reforestation of chestnut trees and larches increased. The reasons for this are that firstly, this region has the appropriate climate to grow larches and Korean nut pine. Secondly, concerning larches, they have a higher price than pitch pines as a whole, and the usage is versatile, such as in the construction of interior wood. It may be considered not only because Korean pine nuts have good quality, but also because foresters can yield pine nuts. Meanwhile, owing to the deficiency of labor force and low economic efficiency, existing plantation forests and natural forests are hardly taken care of through pruning and thinning (Table 7).

3) Felling Structure of Investigation Areas

(1) Felling Forest Trees

The felling size of Sunchon city is 57 ha and an average felling size per one forest owner is 1.4 ha. The felling sizes of species are: pitch pines $56 \%$; pine trees $35 \%$; and chestnut trees and Oak trees $9 \%$. The years of felling in pitch pines and pine trees are mainly $21 \sim 30$ years old, which accounts for $70 \%$ and $79 \%$ of pitch pines and pine trees, respectively.

The felling amount those within Changsu county consists of 78 ha, and an average felling size per one forest owner is $2.4 \mathrm{ha}$. The felling size species are; pitch pines $59 \%$; larches $20 \%$; pine tree $19 \%$. The years of felling in pitch pines are $21 \sim 30$ and $31 \sim 40$

Table 8. Status of cutting by species and age class (1995 1999)

\begin{tabular}{|c|c|c|c|c|c|c|c|c|}
\hline & & $\begin{array}{l}\text { Total } \\
\text { (ha) }\end{array}$ & $\begin{array}{l}\text { Pitch } \\
\text { pine }\end{array}$ & Pine & Larch & $\begin{array}{c}\text { Chest- } \\
\text { nut }\end{array}$ & $\begin{array}{c}\text { Korean } \\
\text { white pine }\end{array}$ & Oak \\
\hline \multirow{9}{*}{ Sunchon } & Total & $\begin{array}{r}57.0 \\
(100.0)\end{array}$ & $\begin{array}{r}31.8 \\
(100.0)\end{array}$ & $\begin{array}{r}19.7 \\
(100.0)\end{array}$ & & \multirow[t]{3}{*}{$\begin{array}{r}2.8 \\
(100.0)\end{array}$} & & \multirow[t]{3}{*}{$\begin{array}{r}2.7 \\
(100.0)\end{array}$} \\
\hline & Below & 1.0 & & 1.0 & & & & \\
\hline & 10years & (1.8) & & $(5.1)$ & & & & \\
\hline & \multirow[t]{2}{*}{$11 \sim 20$} & 8.2 & 4.0 & 3.2 & & \multirow{6}{*}{$\begin{array}{r}0.8 \\
(28.6) \\
2.0 \\
(71.4)\end{array}$} & & \multirow{6}{*}{$\begin{array}{r}1.0 \\
(37.0) \\
1.7 \\
(63.0)\end{array}$} \\
\hline & & $(14.4)$ & (12.6) & $(16.2)$ & & & & \\
\hline & \multirow[t]{2}{*}{$21 \sim 30$} & 40.4 & 22.4 & 15.5 & & & & \\
\hline & & $(70.9)$ & $(70.4)$ & $(78.7)$ & & & & \\
\hline & \multirow[t]{2}{*}{$31 \sim 40$} & 7.4 & 5.4 & & & & & \\
\hline & & $(13.0)$ & $(17.0)$ & & & & & \\
\hline \multirow{14}{*}{ Changsu } & \multirow[t]{2}{*}{ Total } & 77.5 & 45.4 & 14.6 & 15.2 & \multirow{4}{*}{$\begin{array}{r}1.0 \\
(100.0)\end{array}$} & 1.3 & \\
\hline & & $(100.0)$ & $(100.0)$ & $(100.0)$ & $(100.0)$ & & $(100.0)$ & \\
\hline & \multirow[t]{2}{*}{$11 \sim 20$} & 1.3 & 0.1 & 0.1 & 1.1 & & & \\
\hline & & $(1.7)$ & $(0.2)$ & $(0.7)$ & $(7.2)$ & & & \\
\hline & \multirow[t]{2}{*}{$21 \sim 30$} & 33.9 & 20.9 & 6.5 & 5.5 & \multirow{4}{*}{$\begin{array}{r}1.0 \\
(100.0)\end{array}$} & & \\
\hline & & $(43.7)$ & $(46.0)$ & $(44.5)$ & $(36.2)$ & & & \\
\hline & \multirow[t]{2}{*}{$31 \sim 40$} & 31.6 & 24.4 & 1.8 & 5.4 & & & \\
\hline & & $(40.8)$ & $(53.7)$ & (12.3) & $(35.5)$ & & & \\
\hline & \multirow[t]{2}{*}{$41 \sim 50$} & 5.8 & & 3.0 & 1.5 & & 1.3 & \\
\hline & & $(7.5)$ & & $(20.5)$ & (9.9) & & $(100.0)$ & \\
\hline & Above & 1.5 & & 1.5 & & & & \\
\hline & 5lyears & $(1.9)$ & & (10.3) & & & & \\
\hline & Not & 3.4 & & 1.7 & 1.7 & & & \\
\hline & identified & $(4.4)$ & & (11.6) & (11.2) & & & \\
\hline
\end{tabular}

Note: Numerical Values of inside in the parentheses are percent of com-position. 
years old to $46 \%$ and $54 \%$, respectively. In larches were $21 \sim 30$ and $31 \sim 40$ years old to $36 \%$ both all.

However, the reasons why pitch pines and larches, called representative artificial reforestation trees, are being felled in the thinning stages of 21-40 years of age are the following: planting for nuts and fruits in Sunchon city; and low profitability and economic circumstances in Changsu county (Table 8).

(2) Felling Labor Force and Funds.

As far as Sunchon city is concerned, the composition of the felling labor force is; wood dealers $43 \%$, owners themselves plus employment $40 \%$ and owners themselves $8 \%$ in order. But the classes of possession between $3 \sim 5$ ha and $5 \sim 10$ ha account for $60 \%$ and $71 \%$ of owners themselves and the employment, respectively. There were 3 forest owners who felled trees directly and sold them for themselves, or utilized them as fuels against wood dealers, who demanded carrying the felled wood out to roadsides or else proposed low prices for the wood. The reason for felling by the wood dealers is close to half is that the wood that is carried out to the road within the forests, which the wood dealers make, can be used to plant and manage trees for nuts and fruits effectively if the forest owners do not have the proper devices.

So most of the forest owners request positive locations of the roads at the time of construction of them by the wood dealers. The felling funds occupy expenses at the rate of $53 \%$ owners themselves by and by the wood dealers for $43 \%$, so defrayal by owners themselves accounts for more than half.

In Changsu county, the felling by the wood dealers amounts to $94 \%$. The reasons for this are; the complex permission procedures for felling, the risks born at the time of felling wood, and difficulty in obtaining a proper labor force. The wood dealers also account for $94 \%$ of felling funds because they were assisted with the establishment of timber production trees from government, and the wood dealers were entrusted to work for the forest owners and to take assistance money directly from the government.

(3) The Uses and Earnings of Felling Trees.

The use of felled trees are the following; fuel for heating $25 \%$, the negligence of felling the area $25 \%$, sales by the wood dealers $23 \%$ and free concession to the wood dealers $20 \%$. The class of possession under 3 ha accounts for $33 \%$ of fuels for heating and sales by the wood dealers, so there was much use of the felled trees in comparison to other classes. However, the felled trees used as fuels for heating were easy to carry off in location, and the usage was also slight. On the other hand, the usage of pitch and pine trees are; pulpwood, fruits and fish boxes, supporting wood in the shape of lavers, sawdust, wrapping and supporting wood for construction and feed. Most of the oak species were used as basic wood for cultivation of oak mushrooms. The entire felling earnings were $\$ 9,435$. By the species, pitch pines amount to $70 \%$, oak trees $20 \%$, pine trees $11 \%$ in sequence. Earnings per hectare were $\$ 164$. The average income of the 18 people who earned money by felling among the investigation pool of 40 persons was $\$ 785$.

In Changsu county $94 \%$ of the forest owners sold felled trees to the wood dealers, but the usage of pitch pines was same as Sunchon city, and larches were used for engineering and construction decorative wood, sawdust and feed. The felling earnings were $\$ 51,150$, and among them pitch pine trees amount to $66 \%$, oak $20 \%$, larches $9 \%$ and pine trees $6 \%$ by species. The earnings per hectare were $\$ 657$ and the average earnings of 23 people 
who remembered incomes from felling were $\$ 2,228$.

4) Reforestation Structure

(1) Reforestation Labor Force and Reforestation Funds

The reforestation manpower of Sunchon city accounts for the forest owners themselves plus employment at $61 \%$, the owners themselves $21 \%$, the wood dealers $11 \%$ in order, but the classes of those possessing both $3 \sim 5$ ha and 10 ha account for $90 \%$ of the owners themselves plus employment, and a class over 10 ha account for $50 \%$ by the wood dealers. However, in the case of reforestation, there were smaller interventions by the wood dealers in comparison to the felling. This is because it does not demand as many devices and it seems like the intention of the forest owners, who want to input a households labor force to the highest degree to save money. The owners themselves $45 \%$, government assistance $45 \%$ and the wood dealers $11 \%$ supplied reforestation funds, but most of the assistance from the government was money price for seedlings.

In Changsu county, the composition of the forestation labor force was the wood dealers $79 \%$, the owners themselves plus employment $10 \%$ and the owners themselves $10 \%$. So the wood dealers perform the highest rate for reforestation. But the execution of reforestation was decided partly by the conference between the forest owners and the wood dealers as conditions of the location of felling expectant sites and of forestry in the level of felling. The felling funds were from the wood dealers and the owners themselves plus employment amount to $83 \%$ and $10 \%$, respectively, but in the establishment of the timber production forest there was assistance for felling expenses and free concessions of seedlings by the government.

(2) The Grounds for Selection of Species for Reforestation

In Sunchon city, of the 40 forest owners planted $42 \%$ chestnut trees, $32 \%$ Gorosoi (Acer mono), and $17 \%$ persimmon trees. Fifty-nine percent state that the reason for planting chestnut trees is because of fast growth and quick incomes. Eighty-five percent of Gorosoi trees (Acer mono) were planted for the same reason.

In Changsu county, of 32 forest owners planted $41 \%$ of Korean nut pines, $36 \%$ of larches. Solicitation and selection by authorities concerned was the reason for planting, accounted for $35 \%, 24 \%$ as absence of appropriate species to plant, and $24 \%$ as harvest for nuts and fruits. Concerning larches, $47 \%$ of the amount was due to fast growth and fast incomes, $20 \%$ due to solicitation and selection by authorities concerned and $20 \%$ due to the absence of suitable species to plant.

However, the forest owners indicated that main problems of the unilateral selection of tree species by authorities were not smoothly supplying seedling.

5) Forestry incomes and Forest Management Plans

In Sunchon city, 18 forest owners among 40 earned $\$ 40,902$. These forestry incomes are derived from chestnuts $69 \%$, persimmons $20 \%$ and apricot trees $11 \%$ in sequence, but there were no earnings by timber production. The average earnings per one forest owner are $\$ 2,274$, and by the possession scales it is $\$ 4,567$ over 10 ha, $\$ 2,137$ over $3 \sim 5$ ha, $\$ 2,283$ over $5 \sim 10$ ha and $\$ 1,571$ under 3 ha of possessions, in that order. The future forest management plan makes schemes of expansion as $25 \%$, maintenance as $70 \%$ and reduction as $5 \%$, but the expansion accounts for $40 \%$ in the class of over 5 ha of land possession. The purpose of the 10 forest owners hoping for expansion divided into 4 motives: planting trees for nuts and fruits, 3 for producing landscape tree, and 2 for establishing 
Table 9. Forestry incomes and forest management plans

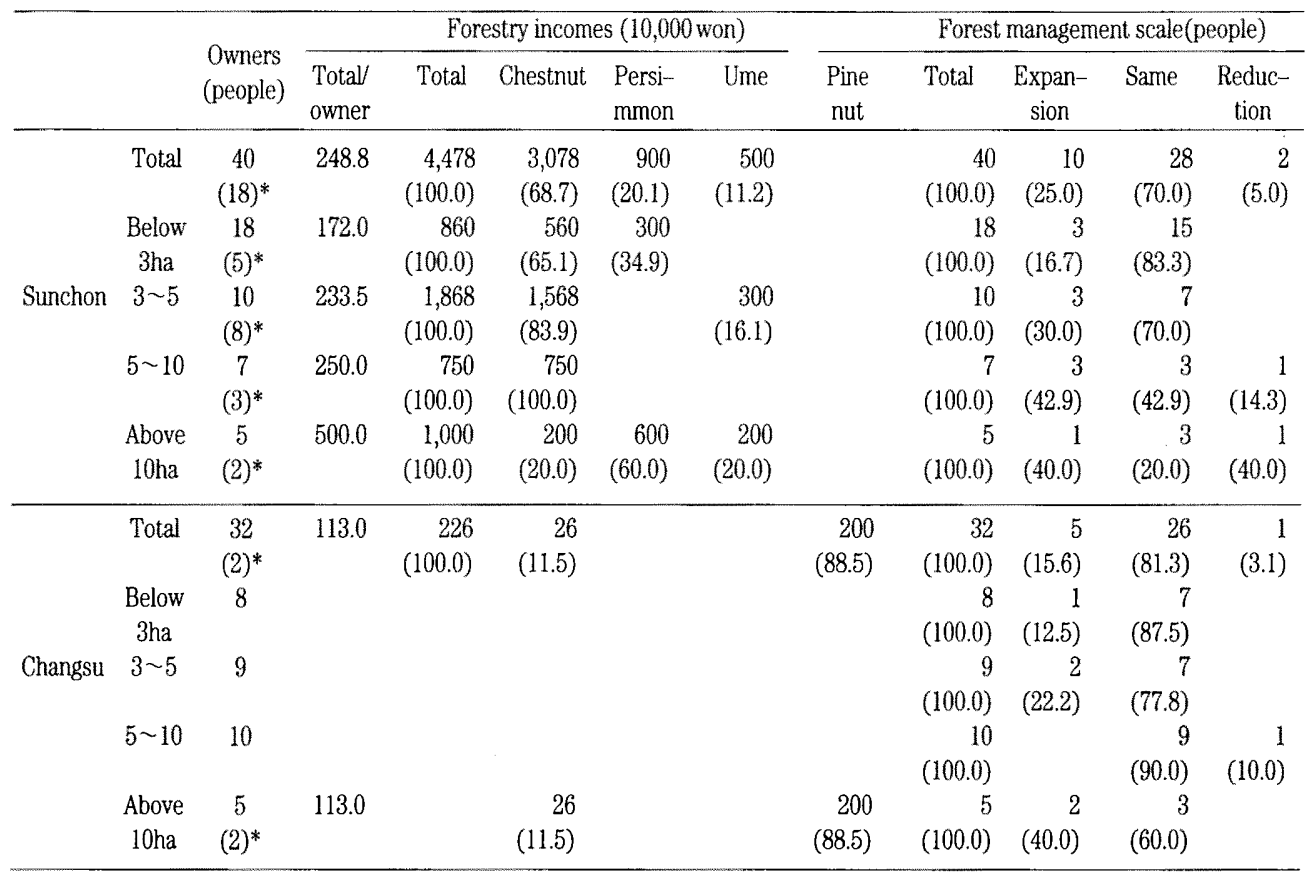

Note: 1) Numerical Values of inside in the parentheses are percent of composition.

2) Numerical Values of inside in the parentheses with star simbol are number of forest owners who had incomes from forest.

timber production forests. Twenty-eight persons are going to maintain these as they are divided into 10: management of trees for nuts and fruits, 10 as ancestral grave mountains and 6 as property, in sequence, but 2 owners are going to reduce replied economic conditions.

In Changsu county, 2 forest owners among 32 earned $\$ 1,826$ from pine nuts and $\$ 237$ from chestnut forestry earnings. Both persons are of the class that owns more than 10 ha. But the damage by animals and the deficiency of labor force were the main reasons to force some forest owners to give up the harvesting of pine nuts. The future forest management plan is expansion at $16 \%$, maintenance at $21 \%$ and reduction at $3 \%$. The $40 \%$ of the class that owns over 10 ha hoped for expansion. In the case of 5 forest owners hoping for expansion, 2 of them want to plant trees for nuts and fruits, 2 for property, 1 for the establishment of timber production forests. Twenty-six persons who are going to maintain the land as it is will do so for the following reasons: 7 for property, 6 for low profitability, 5 for ancestral grave mountains and 4 due to the deficiency of manpower. But one person is going to reduce due to low profitability (Table 9). 


\section{CONCLUSIONS}

In the case of Sunchon city in Chonnam province, the felled trees of pitch and pine trees have not been completely transferred into incomes. It has been considered that this is because of low demand for the felled trees and limited assistance from the government toward the planting of trees for nuts and fruits. However, we can evaluate the realization of future earnings derived from the planting of trees for nuts and fruits as the positive use formation of forests in the meaning that they play a role in elevating the possibility of investment, such as the extension of timber production trees.

On the other hand, the trees with nuts and fruits mostly were planted to the best areas among the possessed forest. So, existing plantation forests and natural forests that had bad conditions, like steep slopes or highlands almost are not being conserved on the grounds of the deficiency of manpower and low profitability. Therefore, we need to take care of existing timber production trees positively, and make use of natural forests intensively.

In Changsu county in Chonbuk province, pitch pines and larches in the state of thinning were cut clearly owing to low profitability and economic conditions, but most of the felled trees were sold, and that brought forestry earnings to the forest owners. It may be considered that this is because of governmental assistance toward the establishment of the timber production trees and secure wood demand. And earnings by the forest management result in the active participation of the forest owners, such as the establishment of timber production forests in spite of the intervention of the wood dealers. However, existing plantation forests and natural forests are not being taken care of because of low profitability. Therefore, we need to attend to timber production forests continuously, and make use of natural forests positively.

The exposed problems from the above examination to solve are the followings:

1. Reckless construction of the carrying out roads within forests have a high possibility to bring about difficulty in forest management, such as erosion and collapsing of sites, so they need to magnify forest roads to strengthen the forest management basis. This will lead to the elevation of the various forest use possibilities for the forest owners.

2 . In order to minimize the economic damage of the forest owners by the intervention of the wood dealers, it need a more positive activity toward wood distribution, such as entrustment and sales agency of forestry cooperatives composed of the forest owners.

3. The labor force is further weakening because of aging and the desperate deficiency of manpower, so it appears to be difficult for the forest owners to participate in forest project actively. Thus, the secure constitutional forestry labor force like 'forest craft workers' is essential.

4. To take care of and expand the timber production forest continuously, the sustaining assistance of the government is necessary and some amount of reward is also necessary for the forest owners who prolong the periods of cutting.

5 . The thinning and reforestation structure of private forests of Sunchon city and Changsu county differ in the use formation of forestry, and especially in clarifying the use of felled trees and sale structures distinctly. It is necessary far broader study about the wood distribution structure and wood market development figures all through the regions. 
6. Finally, without the consideration of non-residential possessed forests, which account for half of private forests, it is impossible to appreciate the whole thinning and reforestation structure of private forests. Therefore, broad researches are necessary for that from this time on.

\section{LITERATURE CITED}

Kang, H. M. 1994 Purposes of forest policy and its issues in Korea, Focused on forestry management cooperatives. Journal of Forest Economics. No 126. 76-81. Japan

Ministry of Agriculture and Forestry. 1999 Studies on the development of high efficiency producing technology and process automation system of gluing-up using domestic timbers. 24-30. Korea

Forestry Administration. 1996 A propulsion plan of principle forest policy. 59pp. Korea

Forestry Administration. 1997a A book of reformation of forest policy. 6-28pp. Korea

Forestry Administration. 1997b History of 50 years of forest policy in Korea. 397-675pp. Korea

Forestry Administration. 1998 Statistical yearbook of forestry. 156-157pp. Korea

Forestry Administration. 1999 Statistical yearbook of forestry. 1-438pp. Korea

Forestry Research Institute. 1991 Forest inventory report. 223pp. Korea

Chang, W. H and H. D. Seok. 1992 A direction of long term reforestation policy through prediction of timber demand by use. The Korea Rural Economics Institute. Research report No 265. 101-105pp. Korea 